\title{
Regulation of GKN1 expression in gastric carcinogenesis: A problem to resolve (Review)
}

\author{
JUDIT ALARCÓN-MILLÁN ${ }^{1}$, DINORAH NASHELY MARTÍNEZ-CARRILLO ${ }^{1}$, \\ OSCAR PERALTA-ZARAGOZA ${ }^{2}$ and GLORIA FERNÁNDEZ-TILAPA ${ }^{1}$ \\ ${ }^{1}$ Clinical Research Laboratory, Faculty of Biological Chemical Sciences, \\ Guerrero Autonomous University, Chilpancingo, Guerrero 39070; \\ ${ }^{2}$ Direction of Chronic Infections and Cancer, Research Center in Infection Diseases, \\ National Institute of Public Health, Cuernavaca, Morelos 62100, México
}

Received January 11, 2019; Accepted July 4, 2019

DOI: 10.3892/ijo.2019.4843

\begin{abstract}
Gastrokine 1 (GKN1) is a protein expressed on the surface mucosa cells of the gastric antrum and fundus, which contributes to maintaining gastric homeostasis, inhibits inflammation and is a tumor suppressor. The expression of GKN1 decreases in mucosa that are either inflamed or infected by Helicobacter pylori, and is absent in gastric cancer. The measurement of circulating GKN1 concentration, the protein itself, or the mRNA in gastric tissue may be of use for the early diagnosis of cancer. The mechanisms that modulate the deregulation or silencing of GKN1 expression have not been completely described. The modification of histones, methylation of the GKN1 promoter, or proteasomal degradation of the protein have been detected in some patients; however, these mechanisms do not completely explain the absence of GKN1 or the reduction in GKN1 levels. Only NKX6.3 transcription factor has been shown to be a positive modulator of GKN1 transcription, although others also have an affinity with sequences in the promoter of this gene. While microRNAs (miRNAs) are able to directly or indirectly regulate the expression of genes at the post-transcriptional level, the involvement of miRNAs in the regulation of GKN1 has not been reported. The present review analyzes the information reported on the determination of GKN1 expression and the regulation of its expression at the transcriptional, post-transcriptional and post-translational levels; it proposes an integrated model that incorporates the regulation of GKN1 expression via transcription factors and miRNAs in H. pylori infection.
\end{abstract}

Correspondence to: Dr Gloria Fernández-Tilapa, Clinical Research Laboratory, Faculty of Biological Chemical Sciences, Guerrero Autonomous University, Avenida Lázaro Cárdenas S/N, Col. Haciendita, Chilpancingo, Guerrero 39070, México

E-mail: gferti@hotmail.com

Key words: gastrokine 1, regulation, microRNAs, transcription factors, Helicobacter pylori, gastric cancer

\section{Contents}

1. Introduction

2. GKN1

3. GKN1, H. pylori infection and gastric cancer

4. GKN1 as a potential biomarker of gastric carcinogenesis

5. Regulation of GKN1 expression in mucous infected by H. pylori or with gastric cancer

6. Conclusion

\section{Introduction}

The gastric epithelium is continually renewed over a lifetime, and is maintained through the proliferation and differentiation of pluripotent stem cells from the isthmus of the gastric gland (1). Stem cells generate precursors that migrate to the gastric lumen and, in turn, generate parietal, gastric zymogenic and foveolar cells. Parietal cells produce hydrochloric acid, while gastric zymogenic cells have a half-life of $\sim 6$ months and synthesize trefoil factor 2 and mucin 6 (1-3). Foveolar cells or surface mucous cells (SMCs), whose half-life is 2-3 days, produce mucous granules, mucin 5AC, gastrokine 1 (GKN1) and trefoil factor 1 (1-3) and play an important role in the restitution of the gastric mucosa in the event of Helicobacter pylori infection (4). The integrity and continuity of the gastric epithelium are rapidly restored after damage, prior to cell proliferation (5). Epithelial restitution is achieved through the migration of epithelial cells from the adjacent area or the cell stratum below the surface cells in the injured area. Epithelial cell restitution in the stomach of mammals takes place in minutes (5).

GKN1 is a protein secreted by SMCs of the gastric antrum and fundus (6), which contributes to maintaining gastric homeostasis, inhibits inflammation and acts as a tumor suppressor (7-16). The expression of GKN1 decreases due to $H$. pylori infection, inflammation or atrophy, and is absent in gastric cancer (17-25).

Although methylation of the GKN1 promoter (20), modification of histones (26) and proteasomal degradation of GKN1 in some cases (27) have been reported, the mechanisms that 
cause a decrease in GKN1 levels or its absence entirely have not been completely described. A total of $\sim 10 \%$ of gastric tumors contain the Epstein-Barr virus (EBV), while the Epstein-Barr nuclear antigen 1 (EBNA1) binds to the promoter region of the GKN1 gene and induces the reduction of its transcription $(28,29)$.

Epigenetic modifications are as important to the regulation of gene expression and the initial stages of disease as genetic modifications. Differential changes have been documented in the expression profile of microRNAs (miRNAs) in gastritis or cancer patients infected with H. pylori (17,30-33), gastric cancer cell lines (34-36), CD4 $\mathrm{T}$ lymphocytes, macrophages, monocytes and dendritic cells (37-39). It has been proposed that some components of $H$. pylori induce the activation of signals that modify the expression of miRNAs in the host cells, and that changes in the global expression profile of miRNAs are related to the genotype of the bacteria (31).

The reduction of GKN1 cannot be explained by mutations in its gene, the methylation of its promoter or the proteasomal degradation of the protein $(20,26,27)$. It is probable that some miRNAs modulate the decreased translation of GKN1 mRNA and, consequently, the reduction of the level of protein in the gastric mucosa. The role of miRNAs in the regulation of GKN1 expression in the normal gastric mucosa, or mucosa infected with $H$. pylori, affected by preneoplasic lesions or with gastric cancer, has not been explored. The present review comprises an analysis of the information published on the regulation of GKN1 expression, proposing a model that integrates the probable regulatory mechanisms at the transcriptional, post-transcriptional and translational levels.

\section{GKN1}

GKN1 (also known as CA11, AMP-18, foveolin or TFIZ2) is a small protein of 181-184 amino acids, specifically expressed in the stomach. The GKN1 gene is located on chromosome 2p13.3 and is composed of six exons separated by relatively short introns (6). GKN1 is composed of: i) A hydrophobic signal peptide in the extreme $\mathrm{NH}_{2}$-terminal, whose processing generates a protein of 160 amino acids with a molecular mass of $18 \mathrm{kDa}$; ii) a BRICHOS domain with three conserved amino acid residues, one aspartic acid residue and two cysteine acid residues; and iii) a COOH-terminal domain $(6,19,40-43)$. GKN1 is a member of the BRICHOS superfamily of proteins, which includes proteins associated with the development of cancer. It is a protein with both an autocrine and paracrine function, which promotes the healing of the mucosa and facilitates cellular restitution and proliferation (43). GKN1 modulates the progression of the cell cycle, cellular proliferation and viability, and apoptosis.

Additionally, GKN1 regulates the production of reactive oxygen species (ROS) and the PI3K/Akt signaling pathway, thus influencing epithelial mesenchymal transition (EMT) and the migration of cancerous cells. GKN1 significantly inhibits the expression of the mRNA of DNA (cytosine-5)-methyltransferase 1 (DNMT1) and histone-lysine N-methyltransferase EZH2 (EZH2) and the activity of DNMT1, functions that link this protein to the inhibition and progression of cancer $(43,44)$.
In the normal gastric mucosa, GKN1 is expressed by epithelial cells on the surface, but not at the depth of the glands of the gastric mucosa $(21,45,46)$. GKN1 reduces the expression of the gastrin receptor, gastrin/cholecystokinin type B receptor, thus inhibiting the cell proliferation induced by this hormone (13). GKN1 activates the $\mathrm{p} 16 / \mathrm{Rb}$ and $\mathrm{p} 21$ signaling pathways, inhibits cell growth and drives cells to senescence (46). GKN1 modulates the expression of cytokines and other inflammatory mediators associated with gastric carcinogenesis, inducing the increased expression of interleukin (IL)-8 and IL-17 and the decreased expression of nuclear factor (NF)- $\kappa$ B, IL-6 and IL-10. Thus, it regulates the immune response and inhibits the progression of epithelial gastric cells to cancerous cells. GKN1 suppresses the activation of NF- $\kappa \mathrm{B}$, and thus inhibits the oncogenic signaling regulated by this transcription factor (9).

\section{GKN1, H. pylori infection and gastric cancer}

GKN1 and H. pylori infection. Infection with $H$. pylori $c a g A^{+}$ strains increases the risk of gastric cancer and is related to the reduced expression of GKN1 in the mucosa (47). In mice infected with $H$. pylori-cag $A^{+}$, the increased expression of the antiapoptotic proteins $\mathrm{Bcl}-2, \mathrm{Bcl}-\mathrm{XL}$ and induced myeloid leukemia cell differentiation protein $\mathrm{Mcl}-1$, as well as $\mathrm{NF}-\kappa \mathrm{B}$ and proteins related to EMT, is found, while the expression of p53, p21, p16 and stress response genes decreases (48). The ectopic expression of GKN1 suppresses the effects of H. pylori-cagA $A^{+}$in the human gastric cancer cell lines AGS, MKN1 and MKN28. Based on these findings, it has been suggested that GKN1 suppresses the malignant transformation of gastric epithelial cells and the progression to gastric cancer (48).

The expression of GKN1 decreases at the mRNA and protein levels in dyspeptic patients and is not detected in the mucosa of subjects with intestinal-type gastric cancer, both with and without $H$. pylori infection $(19,20,21,22,30,49-52)$, or with a diffuse-type cancer $(19,23,25)$.

GKN1 and gastric cancer. GKN1 is absent in human gastric tumors and acts as a tumor suppressor, regulating cell proliferation, apoptosis, migration and invasion in gastric cancer cell lines (10). Stimulating the expression of Fas receptor and the activation of caspase-3, this protein modulates apoptotic signals, playing an important role in the repair of tissues during the early stages of neoplastic transformation (7).

In AGS, MKN-1 and MKN-28 gastric cancer cell lines transfected with GKN1, the re-expression of p16 and a reduction in CDK4, cyclin D1 and E2F levels was observed (8) In gastric cancer SGC7901 cells, GKN1 reduces the expression of MMP2, through the deactivation of NF- $\mathrm{B}$ (15), and induces the expression of miRNA (miR)-185. The extreme 3' untranslated region (UTR) of RhoA mRNA has sequences with affinity to miR-185 and, when this hybrid miRNA with RhoA mRNA reduces its translation, the silencing of RhoA is indirectly mediated by GKN1. c-Myc is a transcription factor that activates RhoA expression and is a target of miR-34a, a miRNA whose expression is promoted by GKN1. Thus, GKN1 also deactivates RhoA via miR-34a. These data suggest that GKN1 inhibits cell motility and invasion by means of the deactivation of RhoA (16). 


\section{GKN1 as a potential biomarker of gastric carcinogenesis}

In $\sim 80 \%$ of gastric cancer cases, symptoms are scarce and non-specific at the early stages of the disease, with the majority of patients diagnosed at an advanced stage with metastasis already occurring $(44,53)$. Thus, the treatment of this malignancy is ineffective and the prognosis for patients is unfavorable. Due to the late diagnosis and consequent limited therapy options for most patients, the 5-year survival rate is $<20 \%$ (54). The lack of criteria and useful markers for early diagnosis has led to studies being conducted on the expression of genes associated with gastric carcinogenesis, with the objective of identifying biomarkers characteristic of premature stages of the disease. GKN1 is one of the proteins considered to be potential biomarker of carcinogenesis.

There are few reports in the available literature on the identification of GKN1 in samples taken from patients. Nardone et al (17) identified the presence of GKN1 in human gastric tissue, finding that its expression decreases in the event of $H$. pylori infection, deteriorates progressively from chronic gastritis to atrophic gastritis, and is not detected in areas in which intestinal metaplasia or $H$. pylori-positive tumors are found (17). GKN1 is absent in cases of gastric cancer without H. pylori infection (17-25). Villano et al (55) analyzed the level of GKN1 mRNA in serum taken from patients with gastric cancer and apparently healthy volunteers, finding no statistically significant differences between patients with cancer and healthy volunteers. The aforementioned results indicate that GKN1 mRNA is not a useful biomarker for the diagnosis of gastric cancer (55). Yoon et al (56) found that the serum levels of GKN1 are significantly lower in gastric cancer patients than in either apparently healthy subjects or patients with hepatocellular and colorectal carcinoma $(\mathrm{P}<0.0001)$. These data suggest that the serum levels of GKN1 may be used for the differentiation of patients with gastric cancer from those with other malignancies of the digestive system and clinically healthy subjects. The authors concluded that the serum concentration of GKN1 may be an informative diagnostic biomarker for gastric cancer (56). Dokhaee et al (44) reported that GKN1 mRNA is significantly reduced in the gastric tissue of patients with gastric cancer, compared to normal tissue. The results led to the hypothesis that GKN1 may be a reliable biomarker for the detection of gastric cancer in its early stages.

The aforementioned data indicate that the measurement of circulating GKN1 concentration, the protein or the mRNA in gastric tissue may be of utility for the early diagnosis of cancer. However, it is necessary to strengthen these findings with more research in patients with preneoplasic lesions (atrophic gastritis, intestinal metaplasia and dysplasia) and cancer in distinct stages of evolution.

\section{Regulation of GKN1 expression in mucosa infected with $H$. pylori or with gastric cancer}

At the chromosomal level, cytogenetic aberrations, such as duplications, translocations, deletions or the loss of heterozygosity in the 2p13 chromosome (in which the GKN1 gene is found) have not been detected $(57,58)$.

The sequence of the GKN1 gene was analyzed in 81 gastric tumors and 40 adenomas, confirming a lack of mutations (20)
These data suggested that the reduction of GKN1 cannot be attributed to cytogenetic aberrations or mutations, and that other mechanisms are involved in the deregulation of this protein.

Gene expression is regulated at different levels, from transcription to translation (59). At the transcriptional level, regulation occurs via epigenetic modifications, such as the modification of histones and the methylation of DNA $(60,61)$. At the post-transcriptional level, the role of small RNAs (miRNAs) in the modulation of translation should be taken into account (62), while at post-translational level, ubiquitination, followed by the proteasomal degradation of the marked protein, is the best-known mechanism involved in the reduction in cytoplasmic levels of proteins (61).

Transcription factors. Transcription factors are able to activate or repress the expression of a gene $(63,64)$. Little is known about the transcriptional regulation of GKN1. Yoon et al (65), using luciferase and chromatin immunoprecipitation assays, confirmed that NKX6.3 is a transcription factor for $G K N 1$, and located the recognition sequence corresponding to NKX6.3 in the promoter region of the GKN1 gene (Fig. 1A). NKX6.3 positively modulates the transcription of $G K N 1$, which is reflected in the increased level of both mRNA and protein (65).

By means of in silico analysis, conducted using the MatInspector (66) (http://www.genomatix.de/matinspector. html), AliBaba2.1 (67) (http://gene-regulation.com/ pub/programs/ alibaba2/index.html) and TfsiteScan 68) (http://www.ifti.org) programs, transcription factors were identified with affinity to recognition sequences in the GKN1 promoter region (Fig. 2A and Table I). It is likely that one or more of these transcription factors, predicted bioinformatically, are involved in the transcriptional regulation of GKN1. Experimental confirmation of the effect exerted by the proposed transcription factors on the modulation of GKN1 expression will improve understanding of the mechanisms involved in the regulation of the expression of this protein.

In patients with gastric pathology, in murine models or in gastric epithelial cell lines, the expression of trans-acting T-cell-specific transcription factor GATA-3 (GATA-3), STAT-1, STAT-3, transcription factor Sp1 (Sp1), cyclic AMP-responsive element-binding protein 3-like protein 4 (CREB), AP-1 transcription factor (AP-1) and Oct-1 increases, while the levels of CCAAT enhancer binding protein- $\alpha(\mathrm{CEBP} \alpha)$ and NKX6.3 decrease $(65,69-82)$. The expression of GATA-3 was found to have increased at different stages of the carcinogenesis associated with $H$. pylori in patient biopsies, murine models and human gastric epithelial cells $(73,74)$.

CagA and OipA of $H$. pylori induce the activation of transcription factors such as AP-1, NF- $\mathrm{kB}$, STAT-3, CREB and nuclear factor of activated T cells (NFAT), which favor the expression of IL-6, and cytokines, which promote inflammation (83-89). IL-6 stimulates the activation of the signaling pathway gp130/STAT3 in gastric cancer cell lines (90), while CagA stimulates the expression of the NFAT transcription factor in AGS cells (88).

The protein Tipa, produced by $H$. pylori, activates the IL-6/STAT3 pathway (89). H. pylori cag $A^{+}$strains induce signaling through the MAPK pathway, thus increasing proliferation and activating transcription factors such as AP-1 (70). 


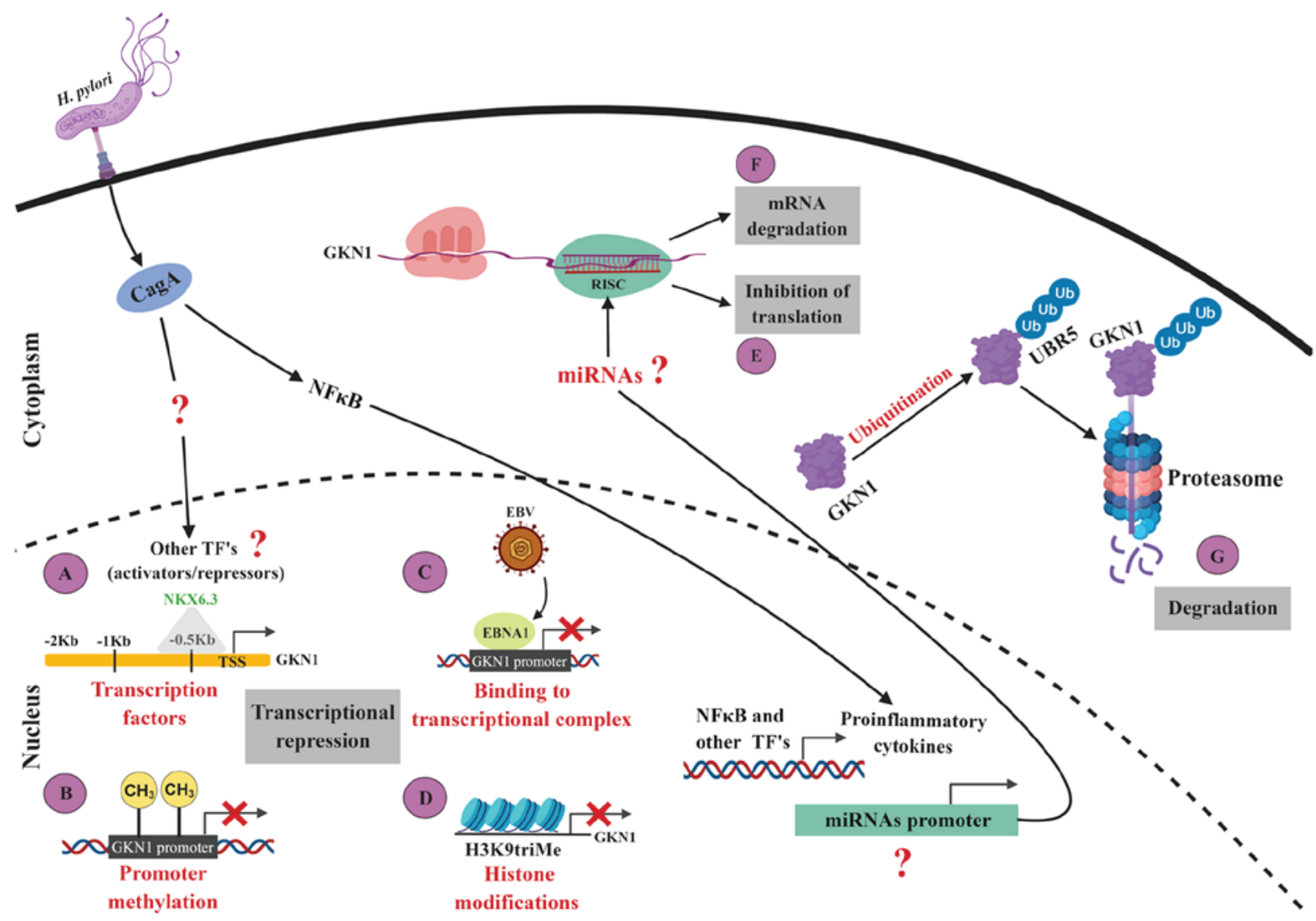

Figure 1. Regulation of GKN1 expression. (A) NKX6.3 is the only transcription factor validated as a positive regulator of GKN1 transcription. It is likely that another transcription factor or factors act as activators or repressors of GKN1 transcription during the infection of the gastric epithelium by H. pylori. Evidence indicates that $H$. pylori activates different signaling pathways that induce the expression of various transcription factors. The decrease in or loss of GKN1 expression in gastric cancer may be a consequence of: (B) GKN1 promoter methylation; (C) EBNA1 binding to the transcriptional complex; or (D) histone modification, such as trimethylation of lysine 9 in histone 3. Additionally, it is possible that the GKN1 mRNA is targeted by some miRNAs. By in silico analysis, miRNAs were found with sequences complementary to sites located in the 3' untranslated region of GKN1 mRNA, and are likely to contribute to its negative post-transcriptional regulation through: (E) Inhibition of translation; or (F) mRNA degradation. The expression of the proposed miRNAs may or not be induced by H.pylori. GKN1 is degraded in the cytoplasm of epithelial cells when (G) the ubiquitin ligase UBR5 marks GKN1 for its degradation in the proteasome. These and other mechanisms can act synergistically to promote the diminution or silencing of GKN1 expression, manifesting as a decreased or absent mRNA and protein expression in gastric tissue or in the circulation. Figure created using BioRender. com. TFs, transcription factors; GKN1, gastrokine 1; UBR5, E3 ubiquitin-protein ligase UBR5; EBNA1, Epstein Barr nuclear antigen 1; EBV, Epstein

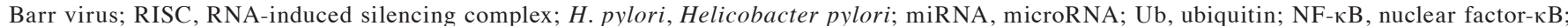
TSS, transcriptional start site.

$\mathbf{A}$

CEBPa, STAT3, AP1, GATA3, NFAT STAT1, SP1, CREB, OCT1

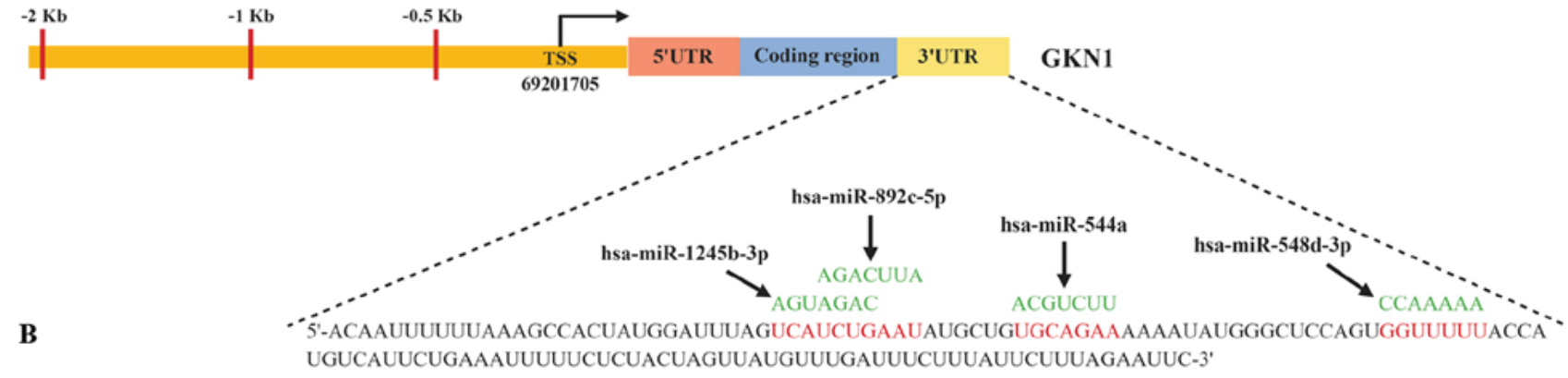

Figure 2. Transcription factors and miRNAs predicted in silico as regulators of GKN1 expression. By in silico analysis (A) transcription factors were identified with affinity to recognition sequences in the GKN1 promotor region and (B) miRNAs were found with sequences complementary to sites located in the 3'UTR of GKN1 mRNA. It is likely that the transcription factors act as activators or repressors of the transcriptional regulation of GKN1, and the miRNAs contribute to post-transcriptional regulation, inhibiting translation or inducing mRNA degradation. Figure created using BioRender.com TSS, transcriptional start site; UTR, untranslated region; miRNA/miR, microRNA; GKN1, gastrokine 1; GATA3, T-cell-specific transcription factor GATA-3; NFAT, nuclear factor of activated T cells; CEBP $\alpha$, CCAAT enhancer binding protein- $\alpha$; AP-1, AP-1 transcription factor; Sp1, transcription factor Sp1; CREB, cyclic AMP-responsive element-binding protein 3-like protein 4 . 
Table I. Transcription factors with affinity to binding sequences in the gastrokine 1 gene promoter region.

\begin{tabular}{llll}
\hline Transcription factor & Number of binding sites & \multicolumn{1}{c}{ Binding sequence $^{\text {Genomic position of binding sequence }}$} \\
\hline GATA-3 & 7 & CAGAGATAAAATG & $68974044-68974056$ \\
CEBP $\alpha$ & 7 & GAAATTGAGGAAGGT & $68974539-68974553$ \\
Oct-1 & 6 & GTCATGCAATTGATC & $68973972-68973986$ \\
AP-1 & 4 & TGATGAGTCAGGT & $68974444-68974456$ \\
STAT-3 & 3 & AGGTTTCCTGGTACACTGG & $68974502-68974520$ \\
Sp1 & 2 & GCTGTGGGCGTGAGTAT & $68974361-68974377$ \\
STAT-1 & 1 & AGTGTACCAGGAAACCTTT & $68974500-68974518$ \\
CREB & 1 & AGGGTCCTATGTAATAAGATT & $68973801-68973821$ \\
NFAT & 1 & CTTTGGAAATCTTATTACA & $68973794-68973812$
\end{tabular}

${ }^{\text {aD }}$ ata obtained from MatInspector. GATA-3, T-cell-specific transcription factor GATA-3; CEBP $\alpha$, CCAAT enhancer binding protein- $\alpha$; AP1-1, AP-1 transcription factor; Sp1, transcription factor Sp1; CREB, cyclic AMP-responsive element-binding protein 3-like protein 4 NFAT, nuclear factor of activated $\mathrm{T}$ cells.

Through toll like receptor (TLR)2 and TLR9, H. pylori activates the MAPK pathway and, downstream, the factors AP-1 and CREB, which positively regulate the transcription of cyclooxygenase 2 (COX-2) (91). CREB and STAT-3 are activated by $H$. pylori and positively regulate the transcription of COX-2 in gastric epithelial cells $(72,83)$. Increased STAT-3 expression has been found in biopsies of the gastric mucosa infected with $H$. pylori $\mathrm{cagA}^{+}(80)$, as well as in cell lines and murine models (86). CagA promotes the phosphorylation of STAT-3 in gastric epithelial cells (92).

In vitro and in vivo experiments have shown that the protein OipA of $H$. pylori stimulates the phosphorylation of STAT-1 (93) and that $H$. pylori alters the STAT-1 signaling induced by IFN- $\gamma$ in gastric epithelial cells. This event may represent an adaptation of the bacteria in order to modulate the immune response of the host mucosa, allowing the bacteria to survive in the stomach (94).

The expression level of the $\mathrm{Sp} 1$ transcription factor increases in gastric adenocarcinoma and is related to the cancer stage, the depth of infiltration and an unfavorable prognosis for patients (82). The expression of Sp1 differs between intestinal-type and diffuse-type cancer, while low-level expression of $\mathrm{Sp} 1$ is related to the progression and metastasis of intestinal-type cancer, in contrast to diffuse-type cancer (95). $\mathrm{Sp} 1$ is essential in the regulation of genes that determine the characteristics of cancer (96). In AGS cells, the ERK1/2 signaling pathway, activated in response to $H$. pylori infection, in turn activates Sp1, which modulates the transcription of vascular endothelial growth factor-A (69). It is probable that the factors AP-1, Oct-1, STAT-1, STAT-3, GATA-3, Sp1, CREB and NFAT, with recognition sequences in the GKN1 promotor and being activated by $H$. pylori, repress the transcription of GKN1 in infected mucosa or mucosa with gastric cancer.

In normal gastric mucosa, $\mathrm{CEBP} \alpha$ is expressed in the foveolar epithelium and is reduced in the tumor tissue of patients with gastric cancer (79), and in the cell lines MKN45 and MKN74 (97). The ectopic expression of CEBP $\alpha$ in gastric cancer cell lines reduces cell viability (97). The level of CEBP $\alpha$ expression gradually decreases in line with the advancing carcinogenesis associated with $H$. pylori infection (73). Given the function of CEBP $\alpha$ in the regulation of the viability of cancerous cells and the fact that GKN1 and CEBP $\alpha$ levels gradually decrease in line with the progress of the lesion, it is probable that this factor is an activator of GKN1 transcription. The reduced expression of CEBP $\alpha$ and NKX6.3 in gastric cancer may be due to the negative regulation mediated by microRNAs.

DNA methylation. Changes in the methylation of DNA lead to changes in gene expression. The hypermethylation of $\mathrm{CpG}$ islands located in the promoter region of a gene results in the decrease or silencing of the expression of the gene.

The methylation of the GKN1 promoter was previously studied, finding hypermethylation in the $\mathrm{CpG}$ islands of the promoter region in only two of 25 gastric tumors. This evidence indicates that the low or null GKN1 expression in the inflamed tissue, either tumoral or infected by H. pylori, is not due to the methylation of its promoter in all cases (Fig. 1B) (20).

The protein EBNA1 of EBV is able to bind to the promoter region of various genes of the host (28). It has been found to have an affinity with the sequences contained in the GKN1 promoter and, binding at these sites, contributes to the deregulation of GKN1 in gastric cancer associated with Epstein-Barr infection (Fig. 1C) (29). Only a small proportion of gastric tumors contain EBV.

Histone modification. The modification of histones is an epigenetic mechanism influencing gene expression. Altieri et al (26) analyzed six gastric tumors in order to determine whether histone modification contributes to GKN1 regulation. Chromatin immunoprecipitation assays were conducted on a fragment of $600 \mathrm{pb}$ of the GKN1 gene promoter, including the 5'UTR, finding trimethylation in lysine 9 of histone 3 (H3K9triMe), among bases -148 and -310 of the GKN1 gene promoter in the six gastric tumors. H3K9triMe is a gene repression marker that generates binding sites for histone deacetylase I (HDAC1) (98) (Fig. 1D). The inhibition of HDAC1 activity with trichostatin A, a hypomethylating agent, is related to increased GKN1 mRNA levels but not to the protein itself. These findings suggest that the regulation 
of GKN1 may occur at the post-transcriptional level via miRNAs (26).

miRNAs. In the gastric mucosa, miRNAs can be expressed by epithelial cells, infiltrating inflammatory cells, transformed cells or cancerous cells (31). In the regulation of gene expression, miRNAs inhibit the translation or induce the degradation of target transcripts. It is likely that some miRNAs impede the translation of GKN1 mRNA and, consequently, are responsible for the reduction in the protein level, although there are no reports indicating whether a miRNA is involved in the regulation of GKN1 expression to the best of our knowledge.

In order to explore whether GKN1 mRNA has binding sites for one or more miRNAs, an in silico analysis was conducted using programs for predicting miRNA targets: TargetScan (99) (2015, http://www.targetscan.org), miRanda (100) (http://www.microrna.org), miRDB (101) (http://mirdb.org), miRSystem (102) (http://mirsystem.cgm.ntu.edu.tw/index.php) and DianaTools (103) (http://www.microrna.gr/microT-CDS), based on thermodynamic and base complementarity analysis. miRNAs were found with sequences complementary to sites located in the 3'UTR region of GKN1 mRNA (Fig. 2B), four of which are able to hybridize with canonical sites of GKNI mRNA and possess two or three guanine or cytosine residues in the seed region of the miRNA, conferring them greater binding stability. An adenine in position 1 of the 3'UTR region of GKN1 mRNA ensures the recognition of the transcript by the RNA-induced silencing complex. These characteristics increase the probability that a miRNA will interact with the 3'UTR of GKN1 mRNA (Table II).

Multiple prediction programs may be used to locate binding sites for miRNAs in gene transcripts. The results of the analysis facilitated the selection of miRNAs with a higher probability of binding to their target, miR-544a was predicted by five programs, according to the aforementioned criteria. It is highly probable that miR-544a is a regulator of GKN1 $(104,105)$. This proposal is strengthened by experimental data on the expression of miR-544a, which is found at increased levels in gastric cancer cell lines (106). To the best of our knowledge, research has not been conducted on the expression of hsa-miR-1245b-3p, hsa-miR-892c-5p and hsa-miR-548d-3p in the gastric mucosa, be that infected, inflamed, atrophic or with gastric cancer. However, the results of the in silico analysis suggested a high probability that these miRNAs regulate the expression of GKN1, either inhibiting the translation of the transcript or promoting its degradation (Fig. 1E and F).

Currently, $>5,000$ miRNAs are registered on miRBase, while in silico predictions estimate that more than one-third of the human transcriptome can be regulated by miRNAs. In gastric cancer, inflammatory processes and $H$.pylori infection, miRNAs fulfil an important function in the deregulation of gene expression $(31,33)$. GKN1 is absent in cancer, both with and without $H$.pylori, and is reduced in patients with gastritis, in gastric mucosa infected by $H$. pylori and in atrophic gastritis (30). The reduction in or absence of GKN1 transcripts or protein is not completely explained by the studied mechanisms of transcriptional and post-translational regulation. It is likely that some miRNAs regulate $G K N 1$ expression directly or indirectly at the post-transcriptional level.

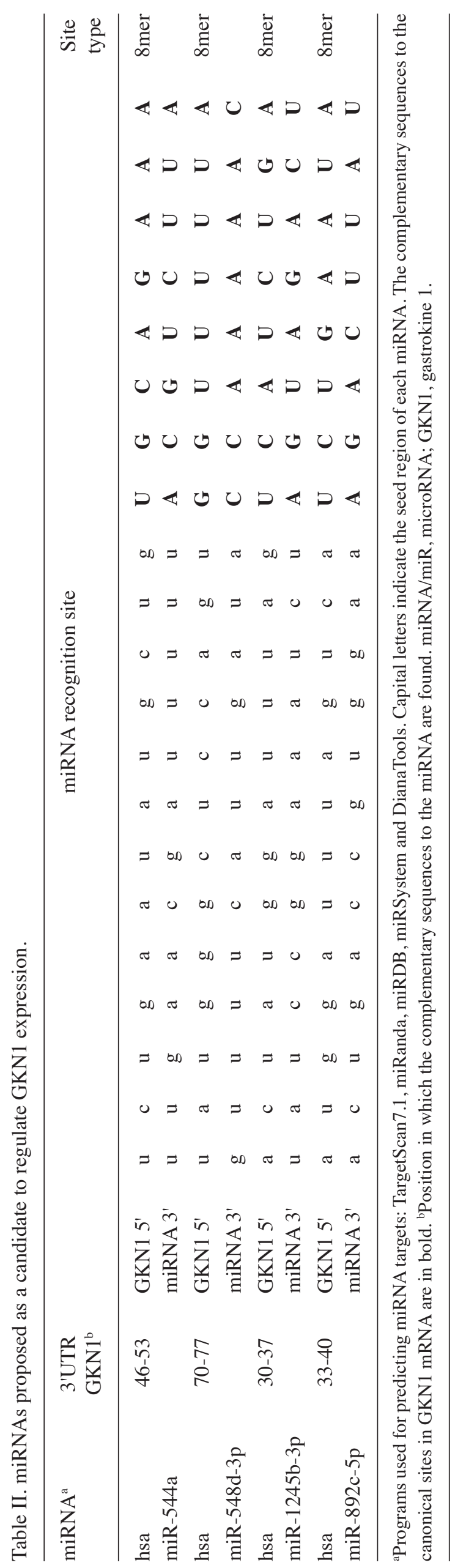




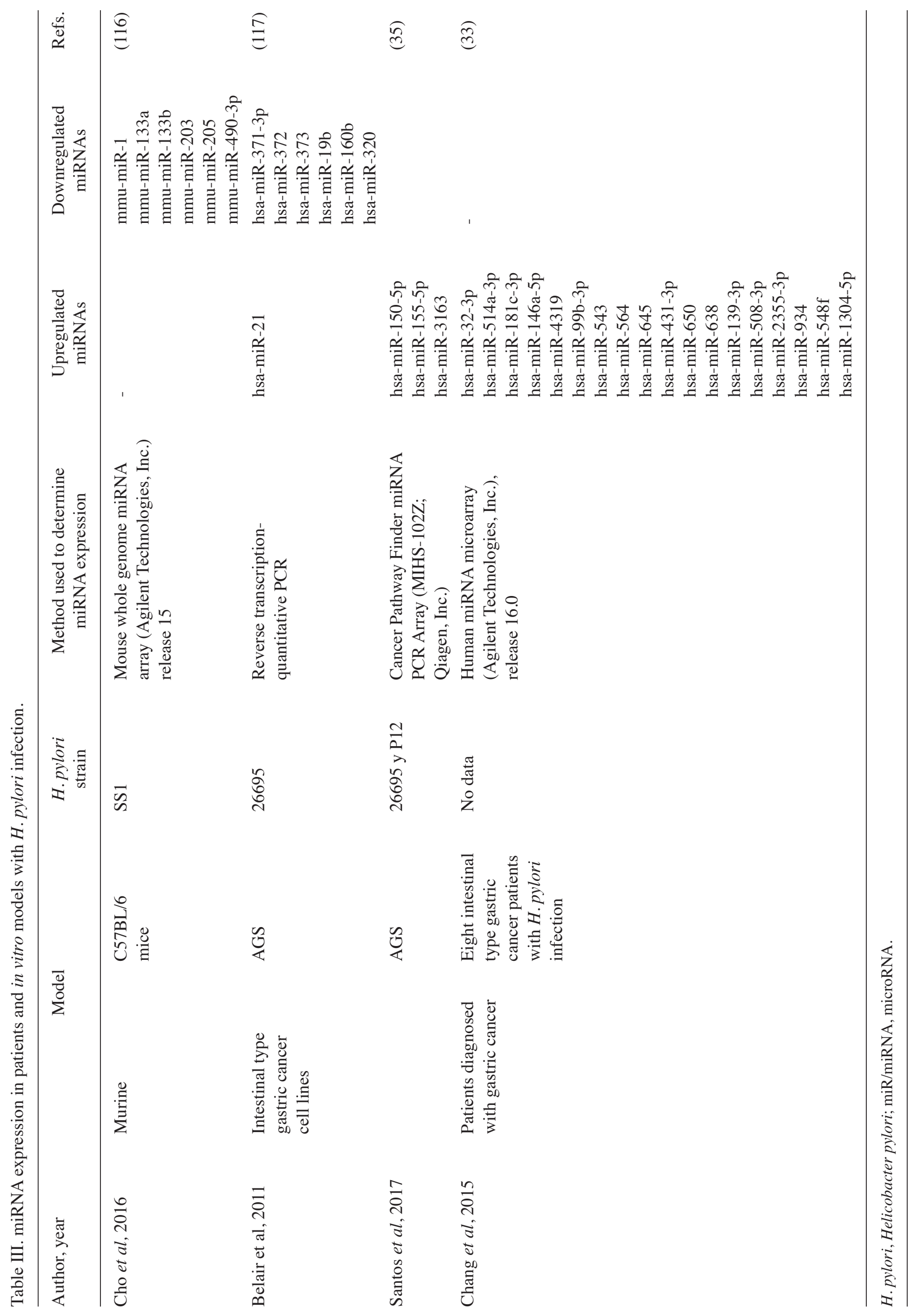




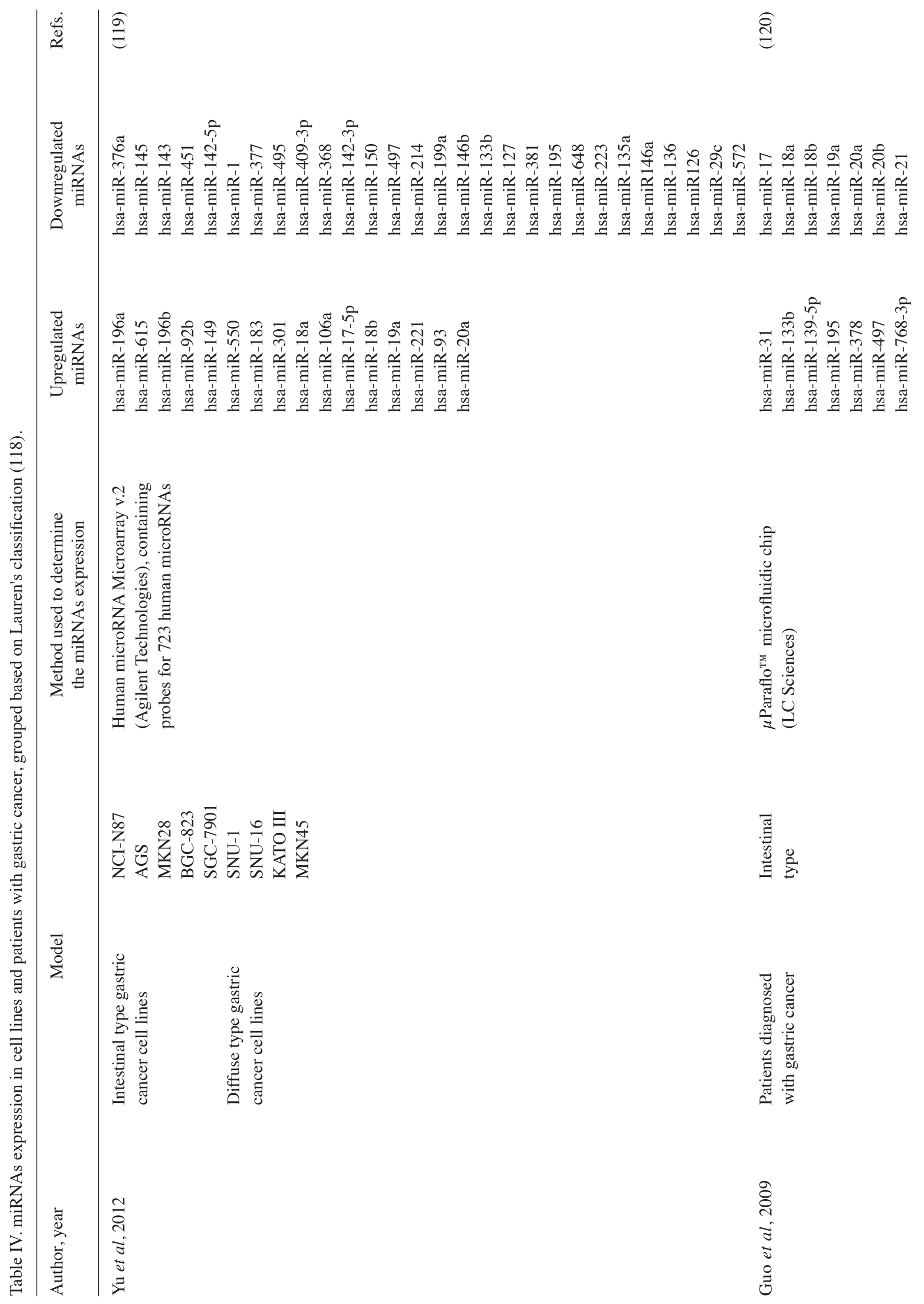




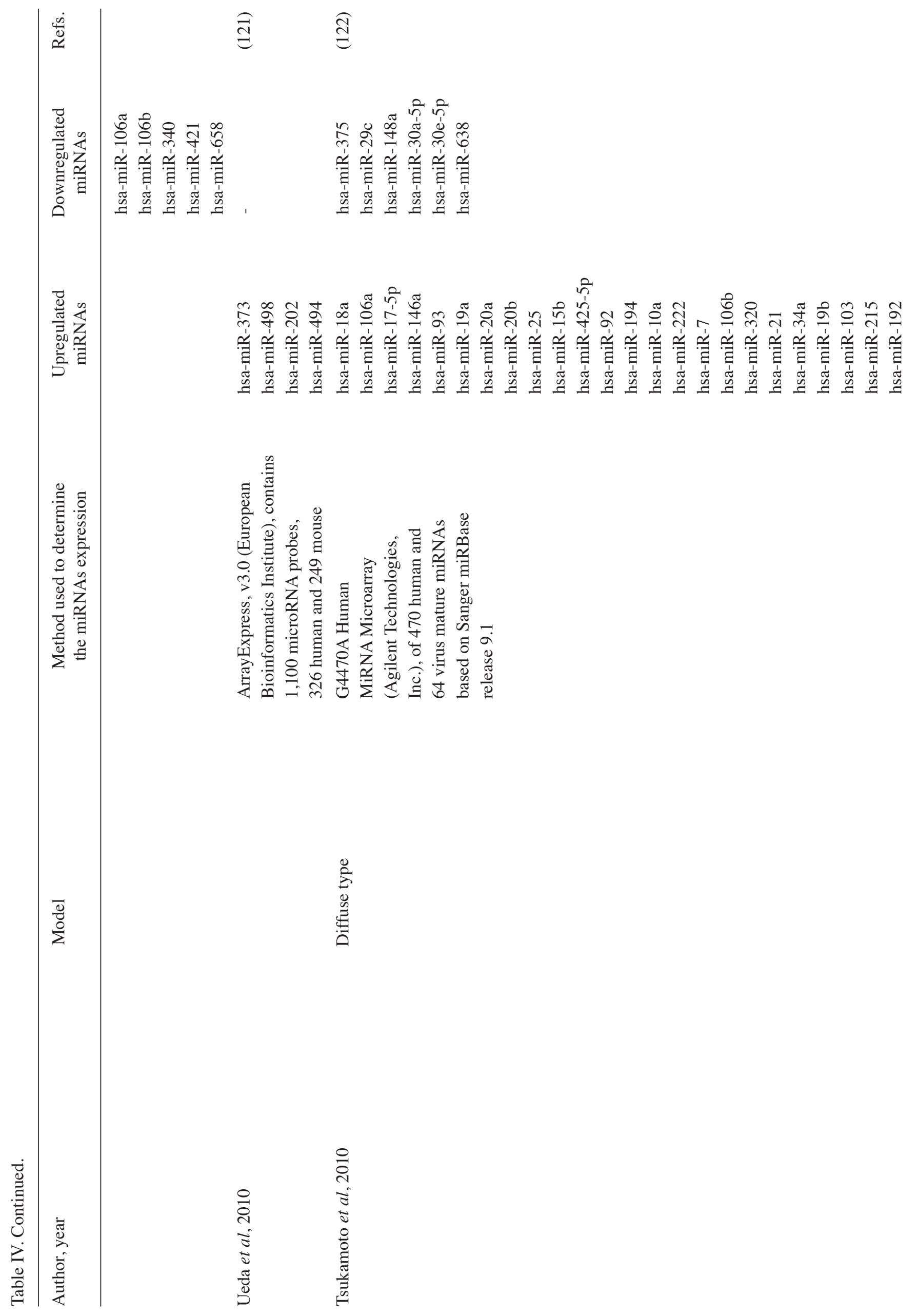




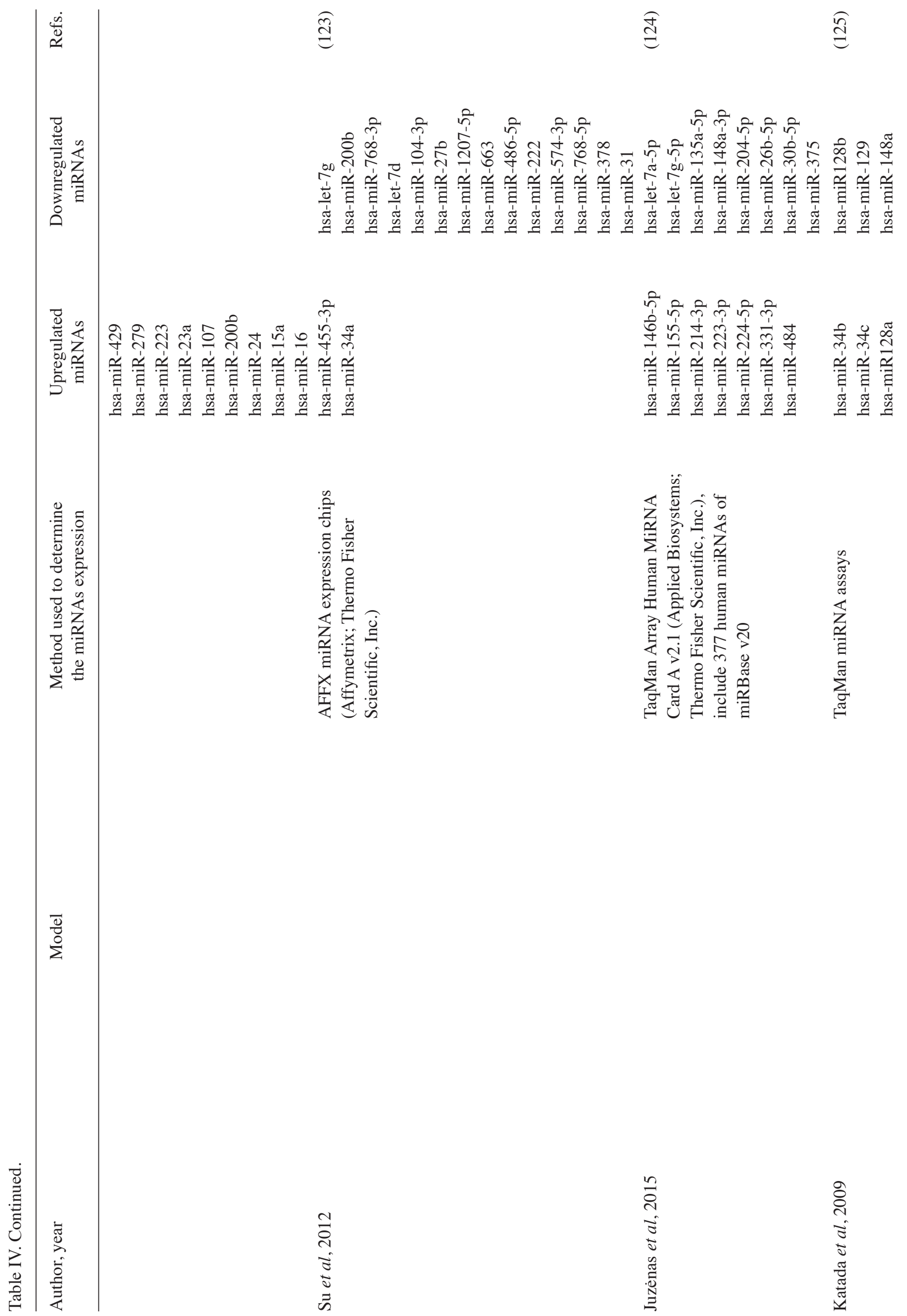


It has been reported that ROS deregulate the expression of miRNAs in tissue infected with $\mathrm{H}$. pylori or gastric cancer tissue $(107,108)$. It is also known that ROS induce a decrease in the number of copies of GKN1 mRNA in tissue infected by H. pylori (48). These data support the hypothesis that, in $H$. pylori infection, ROS alter the expression of miRNAs, among which are those with the GKNl transcript as a target. The cytotoxins VacA and CagA, lipopolysaccharide and peptidoglycan, among other components of $H$. pylori, are able to induce the increased expression of miRNAs that inhibit translation or induce the degradation of the GKN1 transcript, thus modulating the decrease in the levels of this protein.

From the first stages of $H$. pylori infection, the inflammation associated with it causes changes in the expression of proteins and miRNAs, alterations in cell signaling, and unbalanced cell proliferation and apoptosis in gastric epithelial cells, promoting the progression of gastritis to pre-neoplastic and neoplastic lesions (109). The abnormal expression of miRNAs is common in different types of cancer (110), with the evidence indicating changes in the expression profiles of miRNAs in gastric cancer and in mucosa infected by H. pylori.

Alterations in the expression of miRNAs can manifest either as increases or decreases (111). In the gastric mucosa, both with and without $H$. pylori infection, it has been found that miRNAs with changes in their expression levels in response to $H$. pylori can be similar to or different from those observed in gastric cancer with a negative result for bacteria (31) (Tables III and IV). Chang et al (33) found that hsa-miR-99b-3p, hsa-miR-564 and hsa-miR-658 expression increased in cancerous tissue infected with $H$. pylori, while hsa-miR-204-5p, hsa-miR-338-5p, hsa-miR-375 and hsa-miR-548c-3p were found to be overexpressed in cancer tissue without $H$.pylori (33).

In infected mucosa, hsa-miR-223 expression was found to be increased, while in mucosa without $H$. pylori, hsa-miR-203, hsa-miR-204, hsa-miR-455, hsa-miR-141 and hsa-let-7f were found to be overexpressed (31). The levels of let-7, miR-125a and miR-500 were found to be significantly reduced in cells infected with $\operatorname{cag} A^{+}$strains, although not in those infected with $\operatorname{cag} A^{-}$strains. These results indicate that miRNAs participate in gastric pathogenesis, whether associated and not associated with $H$. pylori, and suggest that the CagA oncoprotein of $H$. pylori regulates the differential expression of miRNAs in epithelial gastric cells (31). Increased hsa-miR-127-5p, hsa-miR195, hsa-miR-196a, hsa-miR-206, hsa-miR-216 and miR-488 expression has been found, while decreased hsa-miR-103, hsa-miR-141, hsa-miR-17-3p, hsa-miR34a and let-7i expression has been found in gastric epithelial cells infected with different $H$. pylori-cag $\mathrm{A}^{+}$strains (36).

$H$. pylori is able to modify the expression of miRNAs by means of inflammatory effectors (112). In gastric epithelial cells, the pro-inflammatory cytokines IL-8, tumor necrosis factor- $\alpha$ and IL-1 $\beta$ induce the expression of miR-146a (113), while the oncoprotein CagA positively regulates $c-m y c$, which is related to the decreased expression of miR-26a and miR-101. The decrease in the expression of these miRNAs contributes to increased levels of the histone methyltransferase EZH2 and methyltransferase DNMT3B, which promote the methylation of the let-7 promoter (114). 
Ubiquitination. E3 ubiquitin-protein ligase UBR5 (UBR5) is an E3 ubiquitin ligase that participates in the ubiquitin-proteasome system, regulating protein concentration via ubiquitination and degradation, and is deregulated in different types of cancer (115). UBR5 increases in the cancerous tissues of gastric cancer patients, while an interaction between UBR5 and GKN1 has been observed through immunoprecipitation assays. These results suggest that UBR5 participates in the ubiquitination of GKN1, and that at least part of this protein is sent to be degraded by the proteasome (27) (Fig. 1G). Thus, UBR5 contributes to the regulation of gastric carcinogenesis, inducing the degradation of tumor suppressing proteins, such as GKN1 (27).

Therefore, promoter methylation, trimethylation of histones and ubiquitination are mechanisms that contribute to the regulation of the GKN1 expression in gastric cancer; however, they do not explain the absence of the protein in cell lines and cancerous human tissue.

\section{Conclusion}

GKN1 plays an important role in the maintenance of gastric homeostasis. In inflamed mucosa, both with and without H. pylori infection, GKN1 levels decrease, while this protein is absent in gastric cancer. The measurement of circulating GKN1 concentration, the protein itself or its mRNA in gastric tissue could be useful for the early diagnosis of cancer. However, little is known about the mechanisms that explain the reduction or silencing of GKN1 expression in gastric carcinogenesis. No mutations or polymorphisms have been found in the GKN1 promoter region, which explains the reduction in the levels of this protein. While the modification of histones seems to be involved in the transcriptional regulation of GKN1, further research is required to confirm its level of participation in the regulation of GKN1 in the population. The information available suggests that the methylation of the $G K N 1$ promotor is an epigenetic mechanism that reduces the transcription rate of the gene. However, this mechanism only occurs in some cases of gastric cancer and, moreover, it is probable that it is determined by the genetic characteristics of the individual or the presence of EBV in the tumor. While only factor NKX6.3 has been confirmed as a positive regulator of $G K N 1$ transcription, in silico analysis suggests the existence of other transcription factors with affinity for sequences in the GKNI promotor region, among which are GATA-3, CEBP- $\alpha$, Oct-1, AP-1, STAT-3, SP1, STAT-1, CREB and NFAT. It is unknown whether miRNAs regulate GKN1 expression at the post-transcriptional level. In silico analysis revealed that hsa-miR-544a, hsa-miR1245b-3p, hsa-miR-892c-5p and hsa-miR-548d-3p have sequences complementary to sites located in the 3 'UTR of GKN1 mRNA. It is likely that, together, they regulate the expression of GKN1 in vivo, in mucosa infected by $H$. pylori or in gastric cancer (Fig. 1). Functional studies are required to show whether miRNAs play a role in the regulation of GKN1 expression. At the post-translational level, UBR5 mediates the ubiquitination of GKN1, marking it for degradation in the proteasome; however, this mechanism does not explain the absence or minimal level of GKN1 expression in gastric cancer. Clarifying the mechanisms that regulate GKN1 expression will contribute useful information for evaluating the possible clinical applications for the detection of this protein in mucosa, or in the circulation of patients with gastric diseases both associated and not associated with $H$. pylori.

\section{Acknowledgements}

Not applicable.

\section{Funding}

This work was supported by a doctoral fellowship from CONACYT to JAM (grant no. 296364).

\section{Availability of data and materials}

Not applicable.

\section{Authors' contributions}

JAM, DNMC, OPZ and GFT contributed the idea, wrote the text, and generated the tables and the figure.

\section{Ethics approval and consent to participate}

Not applicable.

\section{Patient consent for publication}

Not applicable.

\section{Competing interests}

The authors declares that they have no competing interests.

\section{References}

1. Khurana S and Mills JC: The gastric mucosa development and differentiation. Prog Mol Biol Transl Sci 96: 93-115, 2010.

2. Dimaline R and Varro A: Attack and defence in the gastric epithelium - a delicate balance. Exp Physiol 92: 591-601, 2007.

3. Hoffmann W: Self-renewal of the gastric ephitelium from stem and progenitor cells. Front Biosci S5: 720-731, 2013.

4. Mueller A, Merrell DS, Grimm J and Falkow S: Profiling of microdissected gastric epithelial cells reveals a cell type-specific response to Helicobacter pylori infection. Gastroenterology 127: 1446-1462, 2004.

5. Silen W and Ito S: Mechanisms for rapid re-epithelialization of the gastric mucosal surface. Annu Rev Physiol 47: 217-229, 1985.

6. Menheniott TR, Kurklu B and Giraud AS: Gastrokines: Stomach-specific proteins with putative homeostatic and tumor suppressor roles. Am J Physiol Gastrointest Liver Physiol 304: G109-G121, 2013.

7. Rippa E, La Monica G, Allocca R, Romano MF, De Palma M and Arcari P: Overexpression of gastrokine 1 in gastric cancer cells induces Fas-mediated apoptosis. J Cell Physiol 226: 2571-2578, 2011.

8. Yoon JH, Choi YJ, Choi WS, Ashktorab H, Smoot DT, Nam SW, Lee JY and Park WS: GKN1-miR-185-DNMT1 axis suppresses gastric carcinogenesis through regulation of epigenetic alteration and cell cycle. Clin Cancer Res 19: 4599-4610, 2013

9. Yoon JH, Cho ML, Choi YJ, Back JY, Park MK, Lee SW, Choi BJ, Ashktorab H, Smoot DT, Nam SW, et al: Gastrokine 1 regulates NF- $\mathrm{kB}$ signaling pathway and cytokine expression in gastric cancers. J Cell Biochem 114: 1800-1809, 2013.

10. Kim O, Yoon JH, Choi WS, Ashktorab H, Smoot DT, Nam SW, Lee JY and Park WS: GKN2 contributes to the homeostasis of gastric mucosa by inhibiting GKN1 activity. J Cell Physiol 229: 762-771, 2014. 
11. Yoon JH, Seo HS, Choi WS, Kim O, Nam SW, Lee JY and Park WS: Gastrokine 1 induces senescence and apoptosis through regulating telomere length in gastric cancer. Oncotarget 5: 11695-11708, 2014.

12. Chen P, Li YC and Toback FG: AMP-18 targets p21 to maintain epithelial homeostasis. PLoS One 10: e0125490, 2015.

13. Kim O, Yoon JH, Choi WS, Ashktorab H, Smoot DT, Nam SW, Lee JY and Park WS: Gastrokine 1 inhibits gastrin-induced cell proliferation. Gastric Cancer 19: 381-391, 2016.

14. Rippa E, Altieri F, Di Stadio CS, Miselli G, Lamberti A, Federico A, Quagliariello V, Papale F, Guerra G and Arcari P: Ectopic expression of gastrokine 1 in gastric cancer cells up-regulates tight and adherens junction proteins network. Pathol Res Pract 211: 577-583, 2015.

15. Xing R, Cui JT, Xia N and Lu YY: GKN1 inhibits cell invasion in gastric cancer by inactivating the NF-kappaB pathway. Discov Med 19: 65-71, 2015.

16. Yoon JH, Choi WS, Kim O, Choi BJ, Nam SW, Lee JY and Park WS: Gastrokine 1 inhibits gastric cancer cell migration and invasion by downregulating RhoA expression. Gastric Cancer 20: 274-285, 2017.

17. Nardone G, Martin G, Rocco A, Rippa E, La Monica G, Caruso F and Arcari P: Molecular expression of Gastrokine 1 in normal mucosa and in Helicobacter pylori-related preneoplastic and neoplastic gastric lesions. Cancer Biol Ther 7: 1890-1895, 2008.

18. He QY, Cheung YH, Leung SY, Yuen ST, Chu KM and Chiu JF: Diverse proteomic alterations in gastric adenocarcinoma. Proteomics 4: 3276-3287, 2004.

19. Moss SF, Lee JW, Sabo E, Rubin AK, Rommel J, Westley BR May FE, Gao J, Meitner PA, Tavares R, et al: Decreased expression of gastrokine 1 and the trefoil factor interacting protein TFIZ1/GKN2 in gastric cancer: Influence of tumor histology and relationship to prognosis. Clin Cancer Res 14 4161-4167, 2008

20. Yoon JH, Song JH, Zhang C, Jin M, Kang YH, Nam SW, Lee JY and Park WS: Inactivation of the Gastrokine 1 gene in gastric adenomas and carcinomas. J Pathol 223: 618-625, 2011.

21. Mao W, Chen J, Peng TL, Yin XF, Chen LZ and Chen MH: Downregulation of gastrokine-1 in gastric cancer tissues and restoration of its expression induced gastric cancer cells to apoptosis. J Exp Clin Cancer Res 31: 49-58, 2012.

22. Xiao JW, Chen JH, Ren MY, Tian XB and Wang CS: Relationship between expression of gastrokine 1 and clinicopathological characteristics in gastric cancer patients. Asian Pac J Cancer Prev 13: 5897-5901, 2012

23. Choi WS, Seo HS, Song KY, Yoon JH, Kim O, Nam SW, Lee JY and Park WS: Gastrokine 1 expression in the human gastric mucosa is closely associated with the degree of gastritis and DNA methylation. J Gastric Cancer 13: 232-241, 2013

24. Guo XY, Dong L, Qin B, Jiang J and Shi AM: Decreased expression of gastrokine 1 in gastric mucosa of gastric cancer patients. World J Gastroenterol 20: 16702-16706, 2014.

25. Hasan AA, Igci M, Borazan E, Khailany RA, Bayraktar E and Arslan A: Down-regulated gene expression of GKN1 and GKN2 as diagnostic markers for gastric cancer. WASET9: 532-535, 2015.

26. Altieri F, Di Stadio CS, Federico A, Miselli G, De Palma M, Rippa E and Arcari P: Epigenetic alterations of gastrokine 1 gene expression in gastric cancer. Oncotarget 8: 16899-16911, 2017.

27. Yang M, Jiang N, Cao QW, Ma MQ and Sun Q: The E3 ligase UBR 5 regulates gastric cancer cell growth by destabilizing the tumor suppressor GKN1. Biochem Biophys Res Commun 478: $1624-1629,2016$

28. Lu F, Wikramasinghe P, Norseen J, Tsai K, Wang P, Showe L, Davuluri RV and Lieberman PM: Genome-wide analysis of host-chromosome binding sites for Epstein-Barr virus nuclear antigen 1 (EBNA1). Virol J 7: 262, 2010.

29. Lu F, Tempera I, Lee HT, Dewispelaere K and Lieberman PM: EBNA1 binding and epigenetic regulation of gastrokine tumor suppressor genes in gastric carcinoma cells. Virol J 11: 12, 2014.

30. Nardone G, Rippa E, Martin G, Rocco A, Siciliano RA, Fiengo A, Cacace G, Malorni A, Budillon G and Arcari P: Gastrokine 1 expression in patients with and without Helicobacter pylori infection. Dig Liver Dis 39: 122-129, 2007.

31. Matsushima K, Isomoto H, Inoue N, Nakayama T, Hayashi T, Nakayama M, Nakao K, Hirayama T and Kohno S: MicroRNA signatures in Helicobacter pylori-infected gastric mucosa. Int $\mathrm{J}$ Cancer 128: 361-370, 2011
32. Lario S, Ramírez-Lázaro MJ, Aransay AM, Lozano JJ, Montserrat A, Casalots Á, Junquera F, Álvarez J, Segura F, Campo R, et al: microRNA profiling in duodenal ulcer disease caused by Helicobacter pylori infection in a Western population. Clin Microbiol Infect 18: E273-E282, 2012.

33. Chang H, Kim N, Park JH, Nam RH, Choi YJ, Lee HS, Yoon H, Shin CM,Park YS, Kim JM, et al: Different microRNA expression levels in gastric cancer depending on Helicobacter pylori infection. Gut Liver 9: 188-196, 2015.

34. Zhu Y, Jiang Q, Lou X, Ji X, Wen Z, Wu J, Tao H, Jiang T, He W, Wang C, et al: MicroRNAs up-regulated by CagA of Helicobacter pylori induce intestinal metaplasia of gastric epithelial cells. PLoS One 7: e35147, 2012.

35. Santos JC, Brianti MT, Almeida VR, Ortega MM, Fischer W, Haas R, Matheu A and Ribeiro ML: Helicobacter pylori infection modulates the expression of miRNAs associated with DNA mismatch repair pathway. Mol Carcinog 56: 1372-1379, 2017.

36. Chung JW, Jeong SH, Lee SM, Pak JH, Lee GH, Jeong JY and Kim JH: Expression of microRNA in host cells infected with Helicobacter pylori. Gut Liver 11: 392-400, 2017.

37. Sugihara H, Ishimoto T, Watanabe M, Sawayama H, Iwatsuki M, Baba Y, Komohara Y, Takeya M and Baba H: Identification of miR-30 $\mathrm{e}^{*}$ regulation of Bmil expression mediated by tumor-associated macrophages in gastrointestinal cancer. PLoS One 8: e81839, 2013

38. Stumpfova Z, Hezova R, Meli AC, Slaby O and Michalek J: MicroRNA profiling of activated and tolerogenic human dendritic cells. Mediators Inflamm 2014: 259689-259699, 2014

39. Teteloshvili N, Smigielska-Czepiel K, Kroesen BJ, Brouwer E, Kluiver J, Boots AM and van den Berg A: T-cell activation induces dynamic changes in miRNA expression patterns in CD4 and CD8 T-cell subsets. MicroRNA 4: 117-122, 2015.

40. Sánchez-Pulido L, Devos D and Valencia A: BRICHOS: A conserved domain in proteins associated with dementia, respiratory distress and cancer. Trends Biochem Sci 27: 329-332, 2002

41. Hedlund J, Johansson J and Persson B: BRICHOS - a superfamily of multidomain proteins with diverse functions. BMC Res Notes 2: 180-189, 2009.

42. Pavone LM, Del Vecchio P, Mallardo P, Altieri F, De Pasquale V, Rea S, Martucci NM, Di Stadio CS, Pucci P, Flagiello A, et al: Structural characterization and biological properties of human gastrokine 1. Mol Biosyst 9: 412-421, 2013.

43. Yoon JH, Choi YJ, Choi WS, Nam SW, Lee JY and Park WS Functional analysis of the NH2-terminal hydrophobic region and BRICHOS domain of GKN1. Biochem Biophys Res Commun 440: 689-695, 2013.

44. Dokhaee F, Mazhari S, Galehdari M, Bahadori Monfared A and Baghaei K: Evaluation of GKN1 and GKN2 gene expression as a biomarker of gastric cancer. Gastroenterol Hepatol Bed Bench 11 (Suppl 1): S140-S145, 2018.

45. Toback FG, Walsh-Reitz MM, Musch MW, Chang EB, Del Valle J, Ren H, Huang E and Martin TE: Peptide fragments of AMP-18, a novel secreted gastric antrum mucosal protein, are mitogenic and motogenic. Am J Physiol Gastrointest Liver Physiol 285: G344-G353, 2003.

46. Xing R, Li W, Cui J, Zhang J, Kang B, Wang Y, Wang Z, Liu S and $\mathrm{Lu}$ Y: Gastrokine 1 induces senescence through $\mathrm{p} 16 / \mathrm{Rb}$ pathway activation in gastric cancer cells. Gut 61: 43-52, 2012

47. Conteduca V, Sansonno D, Lauletta G, Russi S, Ingravallo G and Dammacco F: H. pylori infection and gastric cancer: State of the art (review). Int J Oncol 42: 5-18, 2013.

48. Yoon JH, Seo HS, Choi SS, Chae HS, Choi WS, Kim O, Ashktorab H, Smoot DT, Nam SW, Lee JY, et al: Gastrokine 1 inhibits the carcinogenic potentials of Helicobacter pylori CagA. Carcinogenesis 35: 2619-2629, 2014

49. Yoshikawa Y, Mukai H, Hino F, Asada K and Kato I: Isolation of two novel genes, down-regulated in gastric cancer. Jpn J Cancer Res 91: 459-463, 2000.

50. Shiozaki K, Nakamori S, Tsujie M, Okami J, Yamamoto $H$, Nagano H, Dono K, Umeshita K, Sakon M, Furukawa H, et al: Human stomach-specific gene, CA11, is down-regulated in gastric cancer. Int J Oncol 19: 701-707, 2001.

51. Oien KA, Vass JK, Downie I, Fullarton G and Keith WN: Profiling, comparison and validation of gene expression in gastric carcinoma and normal stomach. Oncogene 22: 4287-4300, 2003.

52. Oien KA, McGregor F, Butler S, Ferrier RK, Downie I, Bryce S, Burns $S$ and Keith WN: Gastrokine 1 is abundantly and specifically expressed in superficial gastric epithelium, down-regulated in gastric carcinoma, and shows high evolutionary conservation. J Pathol 203: 789-797, 2004. 
53. Koper-Lenkiewicz OM, Kamińska J, Gawrońska B and Matowicka-Karna J: The role and diagnostic potential of gastrokine 1 in gastric cancer. Cancer Manag Res 11: 1921-1931, 2019.

54. Zamanian-Azodi M, Rezaei-Tavirani M, Hasanzadeh H, Rahmati Rad S and Dalilan S: Introducing biomarker panel in esophageal, gastric, and colon cancers; a proteomic approach. Gastroenterol Hepatol Bed Bench 8: 6-18, 2015.

55. Villano V, Di Stadio CS, Federico A, Altieri F, Miselli G, De Palma M, Rippa E and Arcari P: Gastrokine 1 mRNA in human sera is not informative biomarker for gastric cancer. J Negat Results Biomed 15: 14, 2016.

56. Yoon JH, Ham IH, Kim O, Ashktorab H, Smoot DT, Nam SW, Lee JY, Hur H and Park WS: Gastrokine 1 protein is a potential theragnostic target for gastric cancer. Gastric Cancer 21: 956-967, 2018.

57. Noguchi T, Wirtz HC, Michaelis S, Gabbert HE and Mueller W: Chromosomal imbalances in gastric cancer. Correlation with histologic subtypes and tumor progression. Am J Clin Pathol 115: 828-834, 2001

58. Panani AD: Cytogenetic and molecular aspects of gastric cancer: Clinical implications. Cancer Lett 266: 99-115, 2008.

59. Orphanides $G$ and Reinberg D: A unified theory of gene expression. Cell 108: 439-451, 2002.

60. Jaenisch R and Bird A: Epigenetic regulation of gene expression: How the genome integrates intrinsic and environmental signals. Nat Genet 33 (Suppl): 245-254, 2003.

61. Shilatifard A: Chromatin modifications by methylation and ubiquitination: Implications in the regulation of gene expression. Annu Rev Biochem 75: 243-269, 2006.

62. Catalanotto C, Cogoni C and Zardo G: MicroRNA in control of gene expression: An overview of nuclear functions. Int J Mol Sci 17: 1712, 2016

63. Levine $\mathrm{M}$ and Tjian R: Transcription regulation and animal diversity. Nature 424: 147-151, 2003

64. Lambert SA, Jolma A, Campitelli LF, Das PK, Yin Y, Albu M, Chen X, Taipale J, Hughes TR and Weirauch MT: The human transcription factors. Cell 175: 598-599, 2018.

65. Yoon JH, Choi WS, Kim O, Choi SS, Lee EK, Nam SW, Lee JY and Park WS: NKX6.3 controls gastric differentiation and tumorigenesis. Oncotarget 6: 28425-28439, 2015.

66. Cartharius K, Frech K, Grote K, Klocke B, Haltmeier M, Klingenhoff A, Frisch M, Bayerlein $M$ and Werner T: MatInspector and beyond: Promoter analysis based on transcription factor binding sites. Bioinformatics 21: 2933-2942, 2005.

67. Grabe N: AliBaba2: Context specific identification of transcription factor binding sites. In Silico Biol 2: S1-S15, 2002.

68. Ghosh D: Object-oriented transcription factors database (ooTFD). Nucleic Acids Res 28: 308-310, 2000.

69. Strowski MZ, Cramer T, Schäfer G, Jüttner S, Walduck A Schipani E, Kemmner W, Wessler S, Wunder C, Weber M, et al: Helicobacter pylori stimulates host vascular endothelial growth factor-A (vegf-A) gene expression via MEK/ERK-dependent activation of Sp1 and Sp3. FASEB J 18: 218-220, 2004.

70. Mitsuno Y, Yoshida H, Maeda S, Ogura K, Hirata Y, Kawabe T, Shiratori Y and Omata M: Helicobacter pylori induced transactivation of SRE and AP-1 through the ERK signalling pathway in gastric cancer cells. Gut 49: 18-22, 2001.

71. Han JC, Zhang KL, Chen XY, Jiang HF, Kong QY, Sun Y, Wu ML, Huang L, Li H and Liu J: Expression of seven gastric cancer-associated genes and its relevance for Wnt, NF-kappaB and Stat3 signaling. APMIS 115: 1331-1343, 2007.

72. Xiong H, Du W, Sun TT, Lin YW, Wang JL, Hong J and Fang JY: A positive feedback loop between STAT3 and cyclooxygenase-2 gene may contribute to Helicobacter pylori-associated human gastric tumorigenesis. Int J Cancer 134: 2030-2040, 2014.

73. Hu TZ, Huang LH, Xu CX, Liu XM, Wang Y, Xiao J, Zhou L, Luo L and Jiang XX: Expressional profiles of transcription factors in the progression of Helicobacter pylori-associated gastric carcinoma based on protein/DNA array analysis. Med Oncol 32: 265, 2015.

74. Liu X, Cao K, Xu C, Hu T, Zhou L, Cao D, Xiao J, Luo L, Guo Y and Qi Y: GATA-3 augmentation down-regulates Connexin43 in Helicobacter pylori associated gastric carcinogenesis. Cancer Biol Ther 16: 987-996, 2015.

75. Qian J, Kong X, Deng N, Tan P, Chen H, Wang J, Li Z, Hu Y, Zou W, Xu J, et al: OCT1 is a determinant of synbindin-related ERK signalling with independent prognostic significance in gastric cancer. Gut 64: 37-48, 2015.
76. Xu G, Li K, Zhang N, Zhu B and Feng G: Screening driving transcription factors in the processing of gastric cancer. Gastroenterol Res Pract 2016: 8431480, 2016.

77. Shakya A, Cooksey R, Cox JE, Wang V, McClain DA and Tantin D: Oct1 loss of function induces a coordinate metabolic shift that opposes tumorigenicity. Nat Cell Biol 11: 320-327, 2009.

78. Kong Y, Ma LQ, Bai PS, Da R, Sun H, Qi XG, Ma JQ, Zhao RM, Chen NZ and Nan KJ: Helicobacter pylori promotes invasion and metastasis of gastric cancer cells through activation of AP-1 and up-regulation of CACUL1. Int J Biochem Cell Biol 45: 2666-2678, 2013.

79. Regalo G, Resende C, Wen X, Gomes B, Durães C, Seruca R, Carneiro $\mathrm{F}$ and Machado JC: $\mathrm{C} / \mathrm{EBP} \alpha$ expression is associated with homeostasis of the gastric epithelium and with gastric carcinogenesis. Lab Invest 90: 1132-1139, 2010.

80. Jackson CB, Judd LM, Menheniott TR, Kronborg I, Dow C, Yeomans ND, Boussioutas A, Robb L and Giraud AS: Augmented gp130-mediated cytokine signalling accompanies human gastric cancer progression. J Pathol 213: 140-151, 2007.

81. O'Reilly LA, Putoczki TL, Mielke LA, Low JT, Lin A, Preaudet A, Herold MJ, Yaprianto K, Tai L, Kueh A, et al: Loss of NF- $\mathrm{NB} 1$ causes gastric cancer with aberrant inflammation and expression of immune checkpoint regulators in a STAT-1 dependent manner. Immunity 48: 570-583.e8, 2018.

82. Zhang J, Zhu ZG, Ji J, Yuan F, Yu YY, Liu BY and Lin YZ: Transcription factor $\mathrm{Spl}$ expression in gastric cancer and its relationship to long-term prognosis. World J Gastroenterol 11: 2213-2217, 2005

83. Jüttner S, Cramer T, Wessler S, Walduck A, Gao F, Schmitz F, Wunder C, Weber M, Fischer SM, Schmidt WE, et al: Helicobacter pylori stimulates host cyclooxygenase-2 gene transcription: Critical importance of MEK/ERK-dependent activation of USF1/-2 and CREB transcription factors. Cell Microbiol 5: 821-834, 2003.

84. Lu H, Wu JY, Kudo T, Ohno T, Graham DY and Yamaoka Y: Regulation of interleukin-6 promoter activation in gastric epithelial cells infected with Helicobacter pylori. Mol Biol Cell 16: 4954-4966, 2005

85. Bronte-Tinkew DM, Terebiznik M, Franco A, Ang M, Ahn D, Mimuro H, Sasakawa C, Ropeleski MJ, Peek RM Jr and Jones NL: Helicobacter pylori cytotoxin-associated gene A activates the signal transducer and activator of transcription 3 pathway in vitro and in vivo. Cancer Res 69: 632-639, 2009.

86. Zhao J, Dong Y, Kang W, Go MY, Tong JH, Ng EK, Chiu PW, Cheng AS, To KF, Sung JJ, et al: Helicobacter pylori-induced STAT3 activation and signalling network in gastric cancer. Oncoscience 1: 468-475, 2014.

87. Piao JY, Lee HG, Kim SJ, Kim DH, Han HJ, Ngo HK, Park SA, Woo JH, Lee JS, Na HK, et al: Helicobacter pylori activates IL-6-STAT3 signaling in human gastric cancer cells: Potential roles for reactive oxygen species. Helicobacter 21: 405-416, 2016.

88. Yokoyama K, Higashi H, Ishikawa S, Fujii Y, Kondo S, Kato H, Azuma T, Wada A, Hirayama T, Aburatani H, et al: Functional antagonism between Helicobacter pylori CagA and vacuolating toxin VacA in control of the NFAT signaling pathway in gastric epithelial cells. Proc Natl Acad Sci USA 102: 9661-9666, 2005.

89. Chen G, Tang N, Wang C, Xiao L, Yu M, Zhao L, Cai H, Han L, Xie C and Zhang Y: TNF- $\alpha$-inducing protein of Helicobacter pylori induces epithelial-mesenchymal transition (EMT) in gastric cancer cells through activation of IL-6/STAT3 signaling pathway. Biochem Biophys Res Commun 484: 311-317, 2017.

90. Mejías-Luque R, Peiró S, Vincent A, Van Seuningen I and de Bolós C: IL-6 induces MUC4 expression through gp130/STAT3 pathway in gastric cancer cell lines. Biochim Biophys Acta 1783: 1728-1736, 2008

91. Chang YJ,WuMS,LinJTandChenCC:Helicobacterpylori-Induced invasion and angiogenesis of gastric cells is mediated by cyclooxygenase-2 induction through TLR2/TLR9 and promoter regulation. J Immunol 175: 8242-8252, 2005.

92. Lee KS, Kalantzis A, Jackson CB, O'Connor L, Murata-Kamiya N, Hatakeyama M, Judd LM, Giraud AS and Menheniott TR: Helicobacter pylori CagA triggers expression of the bactericidal lectin REG3 $\gamma$ via gastric STAT3 activation. PLoS One 7: e30786, 2012.

93. Yamaoka Y,Kudo T, Lu H, Casola A, Brasier AR and Graham DY: Role of interferon-stimulated responsive element-like element in interleukin-8 promoter in Helicobacter pylori infection. Gastroenterology 126: 1030-1043, 2004. 
94. Mitchell DJ, Huynh HQ, Ceponis PJM, Jones NL and Sherman PM: Helicobacter pylori disrupts STAT1-mediated gamma interferon-induced signal transduction in epithelial cells. Infect Immun 72: 537-545, 2004.

95.Lee HS, Park CK, Oh E, Erkin ÖC, Jung HS, Cho MH, Kwon MJ, Chae SW, Kim SH, Wang LH, et al: Low SP1 expression differentially affects intestinal-type compared with diffuse-type gastric adenocarcinoma. PLoS One 8: e55522, 2013.

96. Beishline $\mathrm{K}$ and Azizkhan-Clifford J: Sp1 and the 'hallmarks of cancer'. FEBS J 282: 224-258, 2015.

97. Tomizawa M, Shinozaki F, Motoyoshi Y, Sugiyama T, Yamamoto $S$ and Ishige N: CCAAT/enhancer-binding protein $\alpha$ decreases the viability of gastric cancer cells. Oncol Lett 13 4322-4326, 2017.

98. Peterson CL and Laniel MA: Histones and histone modifications. Curr Biol 14: R546-R551, 2004.

99. Agarwal V, Bell GW, Nam JW and Bartel DP: Predicting effective microRNA target sites in mammalian mRNAs. eLife 4: e05005, 2015.

100. John B, Enright AJ, Aravin A, Tuschl T, Sander C and Marks DS : Human microRNA targets. PLoS Biol 3: e264, 2005.

101. Wong $N$ and Wang X: miRDB: An online resource for microRNA target prediction and functional annotations. Nucleic Acids Res 43D: D146-D152, 2015.

102.Lu TP, Lee CY, Tsai MH, Chiu YC, Hsiao CK, Lai LC and Chuang EY: miRSystem: An integrated system for characterizing enriched functions and pathways of microRNA targets. PLoS One 7: e42390, 2012.

103. Maragkakis M, Reczko M, Simossis VA, Alexiou P, Papadopoulos GL, Dalamagas T, Giannopoulos G, Goumas G, Koukis E, Kourtis K, et al: DIANA-microT web server: Elucidating microRNA functions through target prediction. Nucleic Acids Res 37 (Web Server): W273-6, 2009.

104. Sethupathy P, Megraw M and Hatzigeorgiou AG: A guide through present computational approaches for the identification of mammalian microRNA targets. Nat Methods 3: 881-886, 2006.

105. Leitão AL, Costa MC and Enguita FJ: A guide for miRNA target prediction and analysis using web-based applications. Methods Mol Biol 1182: 265-277, 2014

106.Zhi Q, Guo X, Guo L, Zhang R, Jiang J, Ji J, Zhang J, Zhang J, Chen X, Cai Q, et al: Oncogenic miR-544 is an important molecular target in gastric cancer. Anticancer Agents Med Chem 13: 270-275, 2013.

107. Chaturvedi R, de Sablet T, Asim M, Piazuelo MB, Barry DP, Verriere TG, Sierra JC, Hardbower DM, Delgado AG, Schneider BG, et al: Increased Helicobacter pylori-associated gastric cancer risk in the Andean region of Colombia is mediated by spermine oxidase. Oncogene 34: 3429-3440, 2015.

108. Ishimoto T, Sugihara H, Watanabe M, Sawayama H, Iwatsuki M, Baba Y, Okabe H, Hidaka K, Yokoyama N, Miyake K, et al: Macrophage-derived reactive oxygen species suppress miR-328 targeting CD44 in cancer cells and promote redox adaptation. Carcinogenesis 35: 1003-1011, 2014.

109.Libânio D, Dinis-Ribeiro $M$ and Pimentel-Nunes $P$ Helicobacter pylori and microRNAs: Relation with innate immunity and progression of preneoplastic conditions. World J Clin Oncol 6: 111-132, 2015.

110. Zhang X, Peng Y, Jin Z, Huang W, Cheng Y, Liu Y, Feng X, Yang $\mathrm{M}$, Huang $\mathrm{Y}$, Zhao Z, et al: Integrated miRNA profiling and bioinformatics analyses reveal potential causative miRNAs in gastric adenocarcinoma. Oncotarget 6: 32878-32889, 2015.
111. Zhang W, Dahlberg JE and Tam W: MicroRNAs in tumorigenesis: A primer. Am J Pathol 171: 728-738, 2007.

112. Noto JM and Peek RM: The role of microRNAs in Helicobacter pylori pathogenesis and gastric carcinogenesis. Front Cell Infect Microbiol 1: 21, 2012

113. Li N, Xu X, Xiao B, Zhu ED, Li BS, Liu Z, Tang B, Zou QM, Liang HP and Mao XH: H. pylori related proinflammatory cytokines contribute to the induction of miR-146a in human gastric epithelial cells. Mol Biol Rep 39: 4655-4661, 2012.

114. Hayashi Y, Tsujii M, Wang J, Kondo J, Akasaka T, Jin Y, Li W, Nakamura T, Nishida T, Iijima $\mathrm{H}$, et al: CagA mediates epigenetic regulation to attenuate let-7 expression in Helicobacter pylori-related carcinogenesis. Gut 62: 1536-1546, 2013.

115. Qi J and Ronai ZA: Dysregulation of ubiquitin ligases in cancer. Drug Resist Updat 23: 1-11, 2015.

116. Cho CH, Yu J and Wu WKK: Identification of pathogenic microRNAs in Helicobacter pylori-associated gastric cancer using a combined approach of animal study and clinical sample analysis. Hong Kong Med J 22 (Suppl 6): 13-18, 2016.

117. Belair C, Baud J, Chabas S, Sharma CM, Vogel J, Staedel C and Darfeuille F: Helicobacter pylori interferes with an embryonic stem cell micro RNA cluster to block cell cycle progression. Silence 2: 7, 2011.

118. Lauren P: The two histological main types of gastric carcinoma: Diffuse and so-called intestinal-type carcinoma. An attempt at a histo-clinical classification. Acta Pathol Microbiol Scand 64: 31-49, 1965

119. Yu BQ, Su LP, Li JF, Cai Q, Yan M, Chen XH, Yu YY, Gu QL, Zhu ZG and Liu BY: microrna expression signature of gastric cancer cells relative to normal gastric mucosa. Mol Med Rep 6: 821-826, 2012

120. Guo J, Miao Y, Xiao B, Huan R, Jiang Z, Meng D and Wang Y: Differential expression of microRNA species in human gastric cancer versus non-tumorous tissues. J Gastroenterol Hepatol 24: 652-657, 2009

121. Ueda T, Volinia S, Okumura H, Shimizu M, Taccioli C, Rossi S, Alder H, Liu CG, Oue N, Yasui W, et al: Relation between microRNA expression and progression and prognosis of gastric cancer: A microRNA expression analysis. Lancet Oncol 11: 136-146, 2010

122. Tsukamoto Y, Nakada C, Noguchi T, Tanigawa M, Nguyen LT, Uchida T, Hijiya N, Matsuura K, Fujioka T, Seto M, et al: MicroRNA-375 is downregulated in gastric carcinomas and regulates cell survival by targeting PDK1 and 14-3-3zeta. Cancer Res 70: 2339-2349, 2010.

123. Su Y, Ni Z, Wang G, Cui J, Wei C, Wang J, Yang Q, Xu Y and Li F: Aberrant expression of microRNAs in gastric cancer and biological significance of miR-574-3p. Int Immunopharmacol 13: 468-475, 2012

124.Juzènas S, Saltenienė V, Kupcinskas J, Link A, Kiudelis G, Jonaitis L, Jarmalaite S, Kupcinskas L, Malfertheiner P and Skieceviciene J: Correction: Analysis of deregulated microRNAs and their target genes in gastric cancer. PLoS One 10: e0135762,2015

125. Katada T, Ishiguro H, Kuwabara Y, Kimura M, Mitui A, Mori Y, Ogawa R, Harata K and Fujii Y: MicroRNA expression profile in undifferentiated gastric cancer. Int J Oncol 34: 537-542, 2009. 